\title{
SOVEREIGN-BANK NEXUS OF TURKEY: AN ANALYSIS OF SOVEREIGN RISK AND BANKING INDUSTRY PERFORMANCE INDICATORS BASED ON CAMELS RATING SYSTEM
}

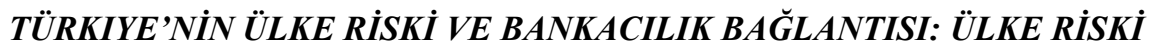 \\ VE BANKACILIK SEKTÖR PERFORMANS INDİKATÖRLERININ CAMELS \\ DERECELENDIRME SISTEMINE GÖRE ANALIZII
}

\author{
Osman ALTAY ${ }^{(1)}$
}

\begin{abstract}
This study aims to examine the relationship between sovereign risk and financial performance of the Turkish banking industry in order to identify the interaction channels between these two. To this end, financial data relating to the Turkish banking industry were analyzed based on the CAMELS rating system and were compared with Turkey's Credit Default Swap rates using the most appropriate causality analysis tools. The results showed that there are significant causal relations between sovereign risk and several banking industry indicators of CAMELS rating groups. Significant results were obtained especially as to the causalities between sovereign risk and CAMELS components, which are Capital Adequacy, Asset Quality, Liquidity, and Sensitivity. Empirical study indicates that 13 variables out 26 variables have causal relationship with credit default swap rates according to Toda and Yamamoto Granger non-causality test results. Although the directions of causality vary among these variables, those results, which indicate influence of credit default swap rates on banking performance indicators, are remarkable.
\end{abstract}

Keywords: Finance, Banking, Risk, Granger Causality

Öz: Bu çalışma, Türkiye'nin ülke riski ile bankacılık sektörünün finansal performansı arasındaki karşılıklı ilişkiyi aralarındaki etkileşim kanallarını ortaya koyacak şekilde analiz etmeyi amaçlamaktadır. Bu amaç doğrultusunda Türkiye'deki bankacılık sektörünün finansal verileri CAMELS derecelendirme sistemine göre analiz edildi ve en uygun nedensellik araçları kullanılarak Türkiye'nin Kredi Temerrüt Swap oranları ile karşılaştırıldı. Sonuçlar, ülke riski ile CAMELS gruplamasında yer alan çeşitli bankacılık sektörü göstergeleri arasında anlamlı nedensellik ilişkisi olduğunu gösterdi. Özellikle ülke riski ile bankaların sermaye yeterliliği, mali yapıları, likidite verileri ve piyasa risklerine duyarlılıkları arasında nedensellik ilişkisi olduğuna dair anlamlı sonuçlara ulaşıldı. Ampirik çalışma, Toda ve Yamamoto Granger nedensellik testi sonuçlarına göre 26 değişkenden 13'ünün kredi temerrüt takas oranları ile nedensellik ilişkisi olduğunu göstermektedir. Bu değişkenler arasında nedensellik yönleri farklılık gösterse de kredi temerrüt takas oranlarının bankacılık performans göstergeleri üzerindeki etkisini gösteren sonuçlar dikkat çekicidir.

Anahtar Kelimeler: Finans, Bankacılık, Risk, Granger Nedensellik

JEL: E50, E58, G21

(1) Beykent Üniversitesi, İktisadi İdari Bilimler Fakültesi, İşletme Bölümü; osmanaltay@beykent.edu.tr, ORCID: 0000-0003-2298-0620

Geliş/Received:02-11-2020; Kabul/Accepted: 16-05-2021 


\section{Introduction and Motivation}

As they are indicated in the literature review part of this study, there exist several studies investigating sovereign creditworthiness and its impact on the funding and liquidity of the banking industry. However, a review of the present studies shows that there is a need for more studies on the mutual relationship between sovereign creditworthiness and the financial performance of banks.

Besides, there are implications that banks adjust their operations to mitigate the adverse effect of worsened creditworthiness of sovereigns (Grigorian \& Manole, 2016: 17). In other words, banks inevitably arrange their operations with sovereign risk concerns in mind, and banks' financial ratios serve as first-hand indicators of this interconnection. On the other hand, sovereign risk measurements take into consideration developments in the financial sector and banking industry. In light of this, in this study, consolidated financial ratios of the Turkish banking industry, as a whole, were analyzed in order to find out any possible interconnectedness.

In economies, sovereign risk concerns might influence a wide array of sectors, which may be financial and/or real sectors. Kirikkaleli and Gokmenoglu (2019) investigated the causal relationship between sovereign credit risk and economic risk. As a result of their empirical study employing Toda-Yamamoto causality, Gradual Shift causality, and Wavelet Coherence tests, they concluded that, in Turkey, changes in sovereign credit risk meaningfully result in fluctuations in economic risk, demonstrating the significance of sovereign credit risk for foretelling economic risk.

With respect to the banking industry, the Bank for International Settlement (BIS) reported in 2011 that higher sovereign risk from late 2009 on has increased the funding cost and had a negative impact on the mixture of funding of some Euro area banks as a consequence of the deterioration in the creditworthiness of the home sovereign. Regarding this interconnection, studies in the literature focus mainly on the spillover effect caused by sovereign risk and its reflection on banks' funding costs, (Andreeva \& Vlassopoulos, 2019; Angeloni \& Wolff, 2012; Buch et al., 2016; De Bruyckere et al., 2013; Bolton \& Jeanne, 2011; Demirgüç-Kunt \& Huizinga, 2013) and it is accepted that decreasing trustworthiness of governments weakens banks' balance sheet due to increasing country risk profiles and cost of funding and it eventually decreases liquidity in the banking sector (Erce, 2015; Mirzaei et al., 2013; Boyd \& De Nicoló, 2005; Wagner, 2010; Ghenimi et al., 2017;Sufian, 2012).Therefore, banks' balance sheets, especially the ratios calculated based on statement items, demonstrate their performance quite clearly. However, there is not an in-depth study on the empirical usefulness of such balance sheet indicators in terms of exposure of banking performance to sovereign risk.

Therefore, the main motivation of this study was to determine this interconnectedness between Turkey's sovereign risk and the financial performance of the banking industry in the country and to throw light on the risk factors in the banking system, which are more prone to the sovereign risk phenomenon. Understanding this interrelation is very important for the formation and implementation of appropriate risk management and financial policies both at micro- and macro-levels, and contribution to the literature with empirical findings based on this curiosity is another motivation of the present study. 


\section{Literature Review}

Channels through which the creditworthiness of a country affects the banking industry can be categorized into four groups. The first group focuses on the relationship between macro-economic risks, the riskiness of banks, and actions of depositors while the second group studies the loan performance of banks in risky market circumstances. The third group analyzes risk management as a matter of market discipline and supervision whereas, in the fourth group, there exist studies examining the influence of macro-economic and sovereign risk variables on bank performance within the context of the 2008 financial crisis. The most prominent research on these groups are presented herein below.

\subsection{Macro-economic Risk and Depositors}

Exploring the relationship between bank deposits and sovereign risk, Levy-Yeyati et al. (2010), based on evidence on the 2000-2002 bank runs in Uruguay and Argentina in their study, highlighted the importance of macro-economic risk and stated that few macro-economic shocks could swiftly lead to large runs. Macro-economic risk influences deposits irrespective of traditional bank-specific features and depositors make a positive and quick reaction to risk in a wider sense than what was regularly presumed by previous scholars (Demirgüç-Kunt \& Huizinga, 2004: 396; Soledad et al., 2001: 33-36).

\subsection{Macro-economic Risk and Loan Performance}

The effects of sovereign risk may shift to the financial system by means of lending channels. There are studies in the literature regarding the loan performance of banks in risky market circumstances. Boyd and De Nicoló (2005) stated that competition in the loan market mitigated the bank risk by decreasing the risk perception of borrowers under high sovereign risk conditions. Wagner (2010) showed that as borrowers feel safer, banks want to balance the consequence of risk measures on their balance sheet and shift to higher-risk lending. As another evidence of the significant relationship between sovereign risk determinants and banking performances, Huizinga \& Laeven (2019: 29-34) examined the procyclicality of loan loss provision for banks in the euro area. Their main finding is that the impact of GDP growth on (provisioning procyclicality) in the euro area is about twice as big as in other countries.

Analyzing the credit risk on the performance of 26 Turkish banks between 2005 and 2017, Ekinci and Poyraz (2019) stated that there is a correlation between credit risk management and productivity of Turkish deposit banks. Podstawski and Velinov (2018) define 'Credit Supply Channel', 'Implicit Bailout Channel', 'Portfolio Channel', 'Collateral Channel', 'Guarantee Channel', and 'Rating Channel' as contagion channels of the sovereign-bank nexus. Ghenimi et al. (2017) investigated primary causes of banking fragility and concluded that credit risk and liquidity risk unconnectedly impact bank stability and that their interaction leads to instability.

\subsection{Risk Management as a Matter of Market Discipline and Supervision}

The $3^{\text {rd }}$ pillar of BASEL II highlights that market discipline potentially strengthens capital regulation and other administrative and control efforts in order to improve soundness and safety in financial systems and banks (BIS, 2013). Furthermore, several academic studies (Cornett et al., 2011; Acharya \& Schnabl, 2010: 69-70; Ashcraft, 2008: 24; Avery et al., 1988: 608-609) support risk management as a matter of market discipline and supervision. By means of a triple-difference approach taking 
advantage of regulatory differences between the USA's state and national banks, Aldunate (2019) figured out that insured banks achieved higher deposit growth and lower funding costs and observed substitution of demand deposits for riskier time deposits.

Chortareas et al. (2011) tested the market power (Structure-Conduct-Performance and Relative Market Power) and the efficient structure (X- and scale efficiency) hypotheses by using a sample of more than 2,500 bank observations between 1997 and 2005 in nine Latin American countries. Their findings supported the efficient structure hypothesis that was found to be predominantly strong for the largest banking markets and capital ratios, and they stated that bank size is probably among the most significant aspects in clearing up higher-than-normal profits for the Latin American banks.

In their study, Podstawski and Velinov (2018) also indicated that the destabilizing impact arising from banks' exposure to sovereign default risk in relatively less developed countries was evident. On the other hand, increased bank exposure was seen to have a stabilizing impact throughout extraordinary times for the countries less influenced by the crisis - namely, France, Germany, the Netherlands, and Austria. They identified this situation as a disciplinary device that stimulates improvement in market discipline.

\subsection{The Sovereign-Bank Nexus}

Deteriorating financial conditions in the banking industry may lead to a reduction in the credit supply to the real economy, which may prompt economic slowdown and downsizing of the sovereign's tax base. Consequently, the creditworthiness of the sovereign will be affected by such a worsened fiscal position. On the other hand, risk contagion from the government to its banking industry is also evident (Andreeva \& Vlassopoulos, 2019: 193). As banks normally hold substantial quantities of public debt, a rise in the apparent probability of sovereign default would worsen the banking industry's balance sheet statuses (Angeloni \& Wolff, 2012; Buch et al., 2016; De Bruyckere et al., 2013: 28-30).

Implications of sovereign debt crises for the banking industry concern researchers with respect to the interrelation between debt management and sovereign default risk (Bolton \& Jeanne, 2011: 191-192; Mishkin \& Carey, 2013: 225-226; Bordo et al., 2010: 8). Brunnermeier et al. (2016) discussed the so-called sovereign-bank nexus or diabolic loop, which was the typical characteristic of the 2009-2012 sovereign debt crisis. Brunnermeier et al. (2016), indicated that worsening sovereign creditworthiness caused a sharp decrease in the market value of banks' holdings of domestic sovereign debt, especially in Ireland, Italy, Portugal, Greece, and Spain. This, in turn, adversely affected the solvency and lending activities of the banks in those countries, and the relevant governments halted the activities of the concerned banks, which enlarged the sovereign distress even further.

There exist recurrent studies analyzing the influence of macro-economic and sovereign risk variables on bank performance in the context of the 2008 financial crisis. For instance, making use of CDS data for 10 Euro-area countries, Erce (2015) indicated that sovereign risk feeds back into bank risk more intensely than bank risk into sovereign risk. Analyzing Pakistani banks within the scope of their study, Shair et al. (2019) concluded that liquidity risk had a positive impact while insolvency risk, credit risk, and competition adversely impacted the profitability of Pakistani banks. 
Besides, they found that, in Pakistan, the capitalization, taxation, size, and GDP growth rate positively influenced banks' profits whereas the development and infrastructure of the banking industry had a negative impact on the profitability. Sufian (2012) examined the performance of 77 Sri Lankan, Bangladeshi, and Pakistani commercial banks from 1997 to 2008 and indicated that economic growth had a significantly positive influence on bank profitability but inflation had no significant influence thereon.

Mirzaei et al. (2013) investigated the impacts of market structure on stability and profitability for 1,929 banks in 40 emerging and advanced economies from 1999 to 2008 by means of integrating the traditional structure-conduct-performance (SCP) and relative-market-power (RMP) hypotheses. They observed that a greater market share resulted in higher bank profitability being biased toward the RMP hypothesis in advanced economies, yet neither hypothesis indicated profitability in emerging economies.

Demirgüç-Kunt and Huizinga (2004) examined the influence of sovereign deficits and indebtedness on credit default swap spreads and bank stock prices. They stated that bank stock prices reflected a negative capitalization of government debt and responded negatively to deficits. They also presented evidence that in 2008 large banks systemically saw a reduction in their market value in countries running large fiscal deficits, and a change in the bank credit default swap spreads in 2008 compared to 2007 reflected the deterioration of countries' public deficits.

The Banking Industry Country Risk Assessment (BICRA) methodology of S\&P assumes that the creditworthiness of a sovereign and its banking industry are strictly related. Moreover, the methodology paper of the S\&P states that most of the factors underlying a sovereign rating are significant in calculating a BICRA score (Gunning, 2012).

Compliant with the findings and expectations of the academic studies, the Banking Regulation and Supervision Agency of Turkey published a guide titled Guide for the Management of Country Risk in 2016. The guide explains sovereign risk matters and lays down principles for the Turkish banks to establish better sovereign risk management procedures (International Monetary Fund, 2017: 46).

As the COVID 19 pandemic has adverse impacts on economies, sovereign and bank nexus became an important concern of the finance sector and the academic studies in this field. It is stated by the reports of the IMF, (Global Financial Stability Report: Markets in the Time of COVID-19), World Bank, (Global Economic Prospects) and Bank of International Settlements, (Annual Economic Report) that social and economic problems caused by the epidemic have also shown their effects on the risk perceptions of the countries. For this reason, there was a record decrease in the country's credit ratings in 2020. Both developing and developed economies were affected by this situation through their finance sectors, especially the banking industry (IMF, 2020; World Bank 2021; BIS 2020). Additionally, in their study Boitan \& Marchewka-Bartkowiak (2021) stated that with respect to their participation in sovereign debt market, banks are more sensitive to the negative information about the pandemic than the positive information reflected by government's reactions and economic stimulus measures. 


\section{Data and Methodology}

The Banks Association of Turkey publishes quarterly consolidated financial statements and ratios of the Turkish banking industry, including every state-owned, private, and foreign bank. Empirical analysis within the scope of this study is based on these data, which complies with the CAMELS rating system. Besides, CDS premium rates are considered as a proxy indicator of sovereign risk in this study and Bloomberg was the source of these data series. Each data series with 68 observations covers the quarterly periods between 2002Q4-2019Q3. Banking data, in the performance ratio format, is available at the web site of The Banks Association of Turkey.

\subsection{Data Selection Based on the CAMELS Rating System}

The CAMELS as an acronym stands for "Capital adequacy, Asset quality, Management, Earnings, Liquidity, and Sensitivity". In 1979, the Uniform Financial Institutions Rating System (UFIRS) was utilized for the first time in the U.S. banking industry. Later, following the U.S. Federal Reserve's recommendation, the system became internationally known with the abbreviation, i.e., CAMEL, reflecting five assessment areas: capital, asset quality, management, earnings, and liquidity. In 1995, the Federal Reserve changed CAMEL to CAMELS, adding the "S" which stands for (S)ensitivity to Market Risk (Federal Deposit Insurance Corporation, 1996). In the literature, there are studies supporting the effectiveness and usefulness of CAMELS ratings in banking performance evaluations (Rahman \& Islam, 2017: 120; Lopez, 1999)

This study employed a total of 26 financial ratios of the Turkish banking industry with respect to the CAMELS rating components. See Table 1 for the ratios falling under the capital adequacy component. The following are explanations according to each component of the CAMELS rating:

Capital Adequacy: The capital adequacy ratio is the ratio of equity and risk-weighted assets, a criterion for controlling the capital powers of banks and their risks. This ratio indicates the level of capital on reserve to handle a certain amount of loss before being at risk insolvent.

Asset Quality: Asset quality is measured based on proportional relevance between total asset amount and credit risk associated with it. While government bonds and Tbills are perceived as good among other items, junk bonds and low-quality loans are items that deteriorate the quality of assets.

Management Quality: Management assessment of banks mainly considers the income and expense structure of the concerned bank. This component of the CAMELS rating reflects the management's capability to administer corporations' daily activities while balancing risk management and profitability in harmony.

Earning Quality: Earning component of the CAMELS is the group of indicators showing a bank's profitability. These ratios are assessed to reveal the earning capacity of banks.

Liquidity: As is commonly accepted, liquidity is the availability of assets that can be easily converted into cash. Liquidity in banking means the capability of a bank to meet its financial obligations by their maturity. 
Sensitivity: The sensitivity component mainly concerns the balance sheet structure of a bank, refers to risk exposures of banks and includes credit concentrations from lending to specific industries such as credit card lending, agricultural lending, medical lending, and energy industry lending. Exposure to foreign exchange, equities, commodities, and derivatives is also included in a sensitivity analysis.

Table 1. Series and their Denominations

\begin{tabular}{|c|c|c|}
\hline $\begin{array}{c}\text { CAMELS } \\
\text { Compo- } \\
\text { nents }\end{array}$ & SERIES & $\begin{array}{c}\text { Denomi- } \\
\text { nation }\end{array}$ \\
\hline $\begin{array}{r}\text { Country } \\
\text { Risk Indi- } \\
\text { cator }\end{array}$ & Capital Adequacy Ratio & CDS \\
\hline \multirow{3}{*}{ 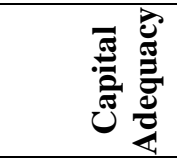 } & Equity / Assets Total & ADEQ \\
\hline & (Equity - Fixed Assets) / Assets Total & EQU \\
\hline & Financial Position Net / Equity & EQUFIX \\
\hline \multirow{5}{*}{ 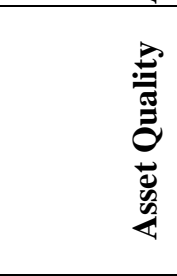 } & Financial Assets (net) / Assets Total & FPOS \\
\hline & Total Loans and Receivables / Assets Total & FASS \\
\hline & Total Loans and Receivables / Deposits Total & TOTL \\
\hline & $\begin{array}{l}\text { Non-Performing Loans (Gross) / Total Loans and } \\
\text { Receivables }\end{array}$ & TOTLR \\
\hline & Fixed Assets / Assets Total & NPRF \\
\hline \multirow{5}{*}{ 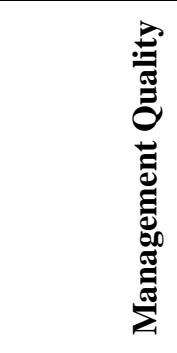 } & $\begin{array}{l}\text { Net Interest Gain After Loan Loss Provisioning / } \\
\text { Total Assets }\end{array}$ & FIXA \\
\hline & $\begin{array}{l}\text { Net Interest Gain After Loan Loss Provisioning / } \\
\text { Total Operational Gain or Loss }\end{array}$ & INTG \\
\hline & Non-Interest Gains (net) / Total Assets & INTGL \\
\hline & Other Operational Losses / Assets Total & NINTG \\
\hline & $\begin{array}{l}\text { Non-Interest Gains (net) / Other Operational } \\
\text { Losses }\end{array}$ & OOPL \\
\hline \multirow{3}{*}{ 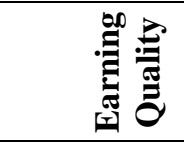 } & Average Profitability of Assets & NINTN \\
\hline & Average Profitability of Equity & APRO \\
\hline & Earnings Before Tax / Assets Total & APRE \\
\hline \multirow{4}{*}{ 氙 } & Liquid Assets / Assets Total & EBTA \\
\hline & Liquid Assets / Short Term Liabilities & LQAS \\
\hline & Local Currency Liquid Assets / Assets Total & LQST \\
\hline & Local Currency Liquid Assets / Assets Total & LCLA \\
\hline \multirow{6}{*}{ 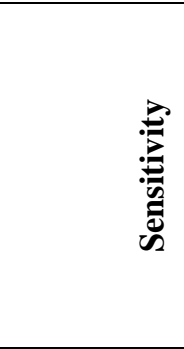 } & Local Currency Assets / Assets Total & LCAA \\
\hline & $\begin{array}{l}\text { Foreign Currency Assets / Foreign Currency Lia- } \\
\text { bilities }\end{array}$ & FCAF \\
\hline & Local Currency Deposits / Total Deposits & LCDT \\
\hline & $\begin{array}{l}\text { Local Currency Loans and Receivables / Total } \\
\text { Loans and Receivables }\end{array}$ & LCLT \\
\hline & Total Deposits / Total Assets & TDTA \\
\hline & Loans Received / Total Assets & LRTA \\
\hline
\end{tabular}


Table 2. Descriptive Statistics of Series

\begin{tabular}{|c|c|c|c|c|c|c|c|c|c|}
\hline Series & $\begin{array}{l}\text { Mea } \\
\text { n }\end{array}$ & $\begin{array}{l}\text { Me- } \\
\text { dia } \\
\text { n }\end{array}$ & $\begin{array}{l}\text { Max } \\
\text { imu } \\
\text { m }\end{array}$ & $\begin{array}{l}\text { Min- } \\
\text { i- } \\
\text { mum }\end{array}$ & $\begin{array}{l}\text { Std. } \\
\text { Dev } \\
\text {. } \\
\end{array}$ & $\begin{array}{l}\text { Skew } \\
\text { ness }\end{array}$ & $\begin{array}{l}\text { Kur- } \\
\text { tosis }\end{array}$ & $\begin{array}{l}\text { Jarque } \\
\text {-Bera }\end{array}$ & $\begin{array}{l}\text { Prob } \\
\text { abil- } \\
\text { ity }\end{array}$ \\
\hline CDS & 5,53 & 5,48 & 6,85 & 4,88 & 0,45 & 1,19 & 4,24 & 20,47 & 0,00 \\
\hline ADEQ & 2,95 & 2,89 & 3,47 & 2,69 & 0,20 & 1,06 & 3,06 & 12,64 & 0,00 \\
\hline EQU & 2,51 & 2,50 & 2,72 & 2,28 & 0,10 & 0,26 & 2,54 & 1,34 & 0,51 \\
\hline EQUFIX & 2,05 & 2,12 & 2,34 & 0,47 & 0,30 & $-3,25$ & 15,83 & 586,48 & 0,00 \\
\hline FPOS & 3,60 & 3,89 & 4,20 & $-0,92$ & 0,79 & $-3,20$ & 16,88 & 662,50 & 0,00 \\
\hline FASS & 3,27 & 3,32 & 3,79 & 2,67 & 0,35 & $-0,33$ & 1,84 & 5,02 & 0,08 \\
\hline TOTL & 3,93 & 4,00 & 4,22 & 3,28 & 0,27 & $-1,04$ & 3,01 & 12,27 & 0,00 \\
\hline TOTLR & 4,44 & 4,49 & 4,79 & 3,68 & 0,33 & $-0,76$ & 2,52 & 7,17 & 0,03 \\
\hline NPRF & 1,39 & 1,22 & 2,92 & 0,96 & 0,48 & 1,72 & 5,43 & 50,41 & 0,00 \\
\hline FIXA & 1,37 & 1,19 & 2,35 & 0,99 & 0,38 & 1,39 & 3,60 & 22,90 & 0,00 \\
\hline INTG & 0,64 & 0,74 & 1,67 & $-0,92$ & 0,56 & $-0,48$ & 2,52 & 3,30 & 0,19 \\
\hline INTGL & 4,02 & 4,05 & 4,22 & 3,45 & 0,15 & $-2,09$ & 7,64 & 110,37 & 0,00 \\
\hline NINTG & 0,05 & 0,05 & 1,59 & $-1,20$ & 0,64 & 0,09 & 2,56 & 0,64 & 0,73 \\
\hline OOPL & 0,32 & 0,41 & 1,53 & $-1,20$ & 0,65 & $-0,33$ & 2,39 & 2,31 & 0,32 \\
\hline NINTN & 4,34 & 4,34 & 5,04 & 3,86 & 0,24 & 0,31 & 3,25 & 1,25 & 0,54 \\
\hline APRO & 0,64 & 0,59 & 1,48 & 0,18 & 0,29 & 0,24 & 2,46 & 1,49 & 0,48 \\
\hline APRE & 2,74 & 2,66 & 3,60 & 2,37 & 0,24 & 0,74 & 3,77 & 7,94 & 0,02 \\
\hline EBTA & 0,25 & 0,34 & 1,16 & $-1,20$ & 0,58 & $-0,49$ & 2,52 & 3,38 & 0,18 \\
\hline LQAS & 3,35 & 3,42 & 3,68 & 2,62 & 0,27 & $-1,71$ & 5,25 & 47,37 & 0,00 \\
\hline LQST & 3,95 & 4,00 & 4,31 & 3,25 & 0,27 & $-1,50$ & 4,90 & 35,70 & 0,00 \\
\hline LCLA & 2,63 & 2,84 & 3,19 & 0,74 & 0,63 & $-1,88$ & 5,65 & 59,97 & 0,00 \\
\hline LCAA & 4,17 & 4,18 & 4,31 & 3,98 & 0,09 & $-0,42$ & 2,35 & 3,19 & 0,20 \\
\hline FCAF & 4,46 & 4,46 & 4,53 & 4,40 & 0,04 & 0,10 & 2,03 & 2,80 & 0,25 \\
\hline LCDT & 4,08 & 4,12 & 4,24 & 3,74 & 0,12 & $-0,84$ & 2,98 & 8,01 & 0,02 \\
\hline LCLT & 4,20 & 4,24 & 4,32 & 3,73 & 0,12 & $-2,16$ & 7,91 & 120,89 & 0,00 \\
\hline TDTA & 4,10 & 4,12 & 4,20 & 3,99 & 0,06 & $-0,21$ & 1,37 & 8,01 & 0,02 \\
\hline LRTA & 2,40 & 2,40 & 2,69 & 2,00 & 0,16 & $-0,38$ & 2,32 & 2,92 & 0,23 \\
\hline
\end{tabular}

\subsection{Methodology}

In this section, Toda and Yamamoto's (1995) approach was used to test the causality relationship between banking performance indicators and sovereign risk indicator. This approach involves a modified Wald (MWALD) test in an augmented Vector Autoregression (VAR) model and does not necessitate pretesting for the cointegration assets of the system. According to Toda and Yamamoto (1995), economic variables could be integrated into different orders, non-cointegrated, or both cases can be valid at the same time. Error Correction Model (ECM) cannot be applied for Granger causality tests in these cases. Therefore, Toda and Yamamoto (1995) developed an alternative test, regardless of the order of integration, cointegration, noncointegration, and arbitrary order of the series. This procedure allows performing causality testing between integrated variables on the asymptotic theory.

The main idea behind Toda and Yamamoto's (1995) approach is to artificially enlarge the true delay length of the VAR model by the maximal order of integration that may take place in the process. This extra lag procedure of Toda and Yamamoto was enhanced by other researchers as well (Giles \& Mirza, 1999; Rambaldi \& Doran, 
1996; Zapata \& Rambaldi, 1997). They confirmed that regardless of the integration or cointegration features of the variables involved, the extra lag procedure generated an asymptotic chi-square $\left(\chi^{2}\right)$ null distribution for the Wald Granger non-causality test statistic in a VAR system. Achieving valid test results regardless of the integration and cointegration features of the variables is the main advantage of this approach.

To sum up, Toda and Yamamoto's (1995) approach is a modified version of the Granger causality test. This approach requires the implementation of specific subtest stages, which are an approximation of the order of integration of the variables, the maximum delay length of the variables in the VAR, the long-run relationship between the variables in the VAR, and finally the testing of the hypothesis of Granger nocausality, as indicated above. All models and analyses were conducted in Eviews software.

\subsection{Model}

The approach requires a proper selection of the optimal delay length in the first place. Integration levels of variables were found with the aid of the Augmented DickeyFuller (ADF) and Phillps-Perron (PP) unit root tests. For the delay length selection, criteria consisting of the Akaike information criterion (AIC), the Schwarz criterion (SC), the sequential modified LR test statistic (LR), the Hannan Quinn (HQ), and the final prediction error (FPE) were simultaneously used. The maximum order of integration matched by most of these six different criteria was obtained, and this number $\left(\mathrm{d}_{\text {max }}\right)$ was summed by the number difference level $(\mathrm{p})$ where stationarity of the variable was obtained and eventually, when a bivariate linear autoregressive model of the two variables $\mathrm{X} 1$ and $\mathrm{X} 2$ was considered, a VAR $\left(\mathrm{p}+\mathrm{d}_{\max }\right)$ model was constructed as follows:

$Y_{t}=a_{0}+a_{1} Y_{t-1}+\ldots+a_{p} Y_{t-p}+b_{1} X_{t-1}+\ldots+b_{p} X_{t-p}+u_{t}$

$X_{t}=c_{0}+c_{1} X_{t-1}+\ldots+c_{p} X_{t-p}+d_{1} Y_{t-1}+\ldots+d_{p} Y_{t-p}+v_{t}$

Testing $\mathrm{H}_{0}: \mathrm{b}_{1}=\mathrm{b}_{2}=0=\ldots=\mathrm{b}_{\mathrm{p}}=0 / \mathrm{d}_{1}=\mathrm{d}_{2}=0=\ldots=\mathrm{d}_{\mathrm{p}}=0$, hypothesis of the test for the nonattendance of Granger causality by approximating the VAR model (1) and (2) could be presented as follows:

$\mathrm{H}_{0}$ : Y does not Granger-cause $\mathrm{X}, \mathrm{H}_{1}$ : Y Granger-cause X

After the determination of the bivariate $\operatorname{VAR}\left(p+d_{m a x}\right)$, the constraint that the coefficients for delay variables of $\mathrm{i}=1,2, \ldots, \mathrm{p}$ equal zero was tested. As the significance of coefficients was tested, extra $n$ lag variables were excluded. This procedure is required to boost the suitability of asymptotic critical values where the variables are integrated (Toda \& Yamamoto, 1995: 227-250).

The Granger causality test is a statistical hypothesis test that is useful to determine whether a one-time series is convenient in forecasting another as well as presenting the direction of causality between variables or not. Granger causality test results contributed much to the main aim of this study in respect of empirical research as they highlighted the causality between the sovereign risk indicator, CDS premium rates, CDS, and banking performance indicators of the Turkish banking industry, which were represented by "PI", i.e., performance indicator. Therefore, causality between sovereign risk indicator and each one of the banking performance indicators was tested separately by running the test procedure for every pair combination. 


$$
\mathrm{CDS}_{\mathrm{t}}=a_{0}+\sum_{i=1}^{p+n} \alpha i \operatorname{CDS}_{\mathrm{t}-1}+\sum_{i=1}^{p+n} \beta i \mathrm{PI}_{\mathrm{t}-1+\mathrm{u}_{\mathrm{t}}}
$$

$\mathrm{PI}_{\mathrm{t}}=a_{0}+\sum_{i=1}^{p+n} \beta i \mathrm{PI}_{\mathrm{t}-1}+\sum_{i=1}^{p+n} \beta i \mathrm{CDS}_{\mathrm{t}-1+\mathrm{V}_{\mathrm{t}}}$

where $\alpha$ and $\beta$ are the coefficients, $t$ is the observation number, $\mathrm{p}$ is the number difference level, $n$ is the $d_{\max }$, which is the maximum order of integration as indicated above, $\mathrm{u}_{\mathrm{t}}$ and $\mathrm{v}_{\mathrm{t}}$ are the error terms, CDS is the Credit Default Swap Premium Rates, and PI represents each single performance indicator.

\subsubsection{The Order of Integration and Optimal Lag Order Determination}

Variables were transformed logarithmic series before testing their order of integration and lag orders. Order of Integration was determined by the Augmented Dickey-Fuller (ADF), Phillps-Perron (PP) and Kwiatkowski-Phillips-Schimidt-Shin (KPSS) test. Probability level 0.05 was achieved at the each order of integration level indicated in the list below. The orders of integrations for each variable and optimal lag lengths in VAR models selected by criteria mentioned in the previous section are presented by the following Table 3 . 
Table 3. Unit Root Test and Lag Length Selection Test Results

\begin{tabular}{|c|c|c|}
\hline $\begin{array}{l}\text { VARIA- } \\
\text { BLES }\end{array}$ & $\begin{array}{c}\text { ADF } \\
\text { Augmented } \\
\text { Dickey-Fuller } \\
\text { Level } \\
\& \\
\text { Difference } \\
\end{array}$ & $\begin{array}{c}\text { Philips-Perron } \\
\text { Level } \\
\& \\
\text { Difference } \\
\end{array}$ \\
\hline CDS & $-6.72 * * *(1), \mathrm{n}$ & $-6.602 * * *(1), \mathrm{n}$ \\
\hline ADEQ & $-8.18 * * *(1), \mathrm{t}+\mathrm{i}$ & $-8.29 * * *(1), \mathrm{n}$ \\
\hline EQU & $-3.878 *(0) \mathrm{t}$ & $-3.878 *(0) \mathrm{t}$ \\
\hline EQUFIX & $-4.35 * * *(1), \mathrm{t}+\mathrm{i}$ & $-4.33 * * *(1), \mathrm{t}+\mathrm{i}$ \\
\hline FPOS & $5.78(0) \mathrm{t}+\mathrm{i}$ & $5.73(0) \mathrm{t}+\mathrm{i}$ \\
\hline FASS & $-2.90(0) \mathrm{t}+\mathrm{i}$ & $-2.63(0) \mathrm{t}+\mathrm{i}$ \\
\hline TOTL & $-0.29(0) \mathrm{t}+\mathrm{i}$ & $-0.44(0) \mathrm{t}+\mathrm{i}$ \\
\hline TOTLR & $-0.77 * * *(1), \mathrm{t}+\mathrm{i}$ & $-4.16 * * *(1), \mathrm{t}+\mathrm{i}$ \\
\hline NPRF & $\begin{array}{c}-0.51(0) \mathrm{t}+\mathrm{i} \\
-3.21 * * *(1), \mathrm{n}\end{array}$ & $\begin{array}{c}-0.79(0) \mathrm{t}+\mathrm{i} \\
-5.12 * * *(1), \mathrm{n} \\
\end{array}$ \\
\hline FIXA & $-4.07 * * *(1), \mathrm{n}$ & $\begin{array}{c}-0.28(0) \mathrm{t}+\mathrm{i} \\
-7.05 * * *(1), \mathrm{n} \\
\end{array}$ \\
\hline INTG & $\begin{array}{c}-7.34(0) \mathrm{t}+\mathrm{i} \\
-6.07 * * *(1), \mathrm{n} \\
\end{array}$ & $-27.26 * * *(1), \mathrm{n}$ \\
\hline INTGL & $-6.71 * * *(1), \mathrm{t}$ & $-10.61 * * *(1), \mathrm{t}$ \\
\hline NINTG & $-2.04 * * *(1), \mathrm{t}+\mathrm{i}$ & $-25.06 * * *(1), \mathrm{t}+\mathrm{i}$ \\
\hline OOPL & $-3.18 * * *(1), \mathrm{n}$ & $-35.63 * * *(1), \mathrm{n}$ \\
\hline NINTN & $-4(0) t$ & $-3.38(0) \mathrm{t}$ \\
\hline APRO & $-3.09(0) \mathrm{i}$ & $-2.41(0) \mathrm{i}$ \\
\hline APRE & $-0.71 * * *(1), \mathrm{n}$ & $-5.28 * * *(1), \mathrm{n}$ \\
\hline EBTA & $-2.71(0) \mathrm{t}$ & $-9.27(0) \mathrm{t}$ \\
\hline LQAS & $-5.94 * * *(1), \mathrm{n}$ & $-7.91 * * *(1), \mathrm{n}$ \\
\hline LQST & $-8 * * *(1), \mathrm{t}$ & $-8 * * *(1), \mathrm{t}$ \\
\hline LCLA & $-8.64 * * *(1), \mathrm{t}$ & $-8.64 * * *(1) \mathrm{t}$ \\
\hline LCAA & $-0.11(0) \mathrm{t}+\mathrm{i}$ & $-0.65(0) \mathrm{t}+\mathrm{i}$ \\
\hline FCAF & $-7.93 * * *(1), \mathrm{n}$ & $-10.50 * * *(1), \mathrm{n}$ \\
\hline LCDT & $-0.591(0) \mathrm{t}+\mathrm{i}$ & $-1.42(0) \mathrm{t}+\mathrm{i}$ \\
\hline LCLT & $-2.20 * * *(1), \mathrm{t}$ & $-6.89 * * *(1), \mathrm{t}$ \\
\hline TDTA & $-2.79(0) \mathrm{t}+\mathrm{i}$ & $-2.81(0) \mathrm{t}+\mathrm{i}$ \\
\hline LRTA & $-2.43(0) \mathrm{t}$ & $-2.66(0) \mathrm{t}$ \\
\hline
\end{tabular}

$*, * *, * *$ show statistical significance at $10 \%, 5 \%, 1 \%$ significance levels. $(\mathrm{t}+\mathrm{i} \mathrm{t}$ and $\mathrm{i}$ represent trend $\&$ intercept, $\mathrm{i}$ intercept, $\mathrm{n}$ none in test method)

\section{Granger Non-Causality Test Results}

As explained in the methodology section, the Toda and Yamamoto Granger noncausality test (Toda and Yamamoto, 1995) requires the selection of the optimal lag for the Granger non-causality Test and the application of an extra lag procedure, $\operatorname{VAR}(p+n)$. At the same time, the coefficients of the causal variable for $p$ lags were 
limited to zero for the Wald test of linear restrictions. This procedure was done for the two equations (equation 1 and equation 2) of each indicator, which were derived from the CAMELS approach. Table 4 displays a summary of the Toda and Yamamoto Granger non-causality Test results.

Table 4. Toda and Yamamoto Granger Non-Causality Test Results

\begin{tabular}{|c|c|c|c|}
\hline $\begin{array}{l}\text { Toda and Yamamoto } \\
\text { Granger Non-causal- } \\
\text { ity } \\
\text { Hypothesis Testing }\end{array}$ & $\begin{array}{l}\text { Chi-squared } \\
\text { test }\end{array}$ & Probability & Granger Causality \\
\hline $\begin{array}{l}\mathrm{H}_{0}: \text { ADEQ } \mid \rightarrow C D S \\
\mathrm{H}_{0}: \text { CDS } \mid \rightarrow \text { ADEQ }\end{array}$ & $\begin{array}{l}\text { CS1:6.09 } \\
\text { CS2:19.08 }\end{array}$ & $\begin{array}{l}\text { Prob1:0.04 } \\
\text { Prob2:0.000 }\end{array}$ & $\begin{array}{l}\text { Bidirectional Causal- } \\
\text { ity }\end{array}$ \\
\hline $\begin{array}{l}\mathrm{H}_{0}: \mathrm{EQU} \mapsto \rightarrow \mathrm{CDS} \\
\mathrm{H}_{0}: \mathrm{CDS} \mapsto \rightarrow \mathrm{EQU}\end{array}$ & $\begin{array}{l}\text { CS } 1: 5.35 \\
\text { CS220.17 }\end{array}$ & $\begin{array}{l}\text { Prob1:0.06 } \\
\text { Prob2:0.000 }\end{array}$ & $\begin{array}{l}\text { Unidirectional Cau- } \\
\text { sality } \\
\text { CDS } \rightarrow \text { EQU }\end{array}$ \\
\hline $\begin{array}{l}\mathrm{H}_{0}: \text { FPOS } \mapsto \rightarrow \text { CDS } \\
\mathrm{H}_{0}: \text { CDS } \mapsto \rightarrow \text { FPOS }\end{array}$ & $\begin{array}{l}\text { CS1:0.71 } \\
\text { CS20.35 }\end{array}$ & $\begin{array}{l}\text { Prob1:0.69 } \\
\text { Prob2:0.83 }\end{array}$ & No Causality \\
\hline $\begin{array}{l}\mathrm{H}_{0}: \text { INTGL } \mid \rightarrow \text { CDS } \\
\mathrm{H}_{0}: \text { CDS } \mid \rightarrow \text { INTGL }\end{array}$ & $\begin{array}{l}\text { CS } 1: 0.41 \\
\text { CS21.07 }\end{array}$ & $\begin{array}{l}\text { Prob1:0.81 } \\
\text { Prob2:0.58 }\end{array}$ & No Causality \\
\hline $\begin{array}{l}\mathrm{H}_{0}: \text { NINTN } \mid \rightarrow C \text { CDS } \\
\mathrm{H}_{0}: \text { CDS } \mapsto \rightarrow \text { NINTN }\end{array}$ & $\begin{array}{l}\text { CS1:2.63 } \\
\text { CS22.79 }\end{array}$ & $\begin{array}{l}\text { Prob1:0.26 } \\
\text { Prob2:0.24 }\end{array}$ & No Causality \\
\hline $\begin{array}{l}\mathrm{H}_{0}: \text { LQAS } \rightarrow \rightarrow \text { CDS } \\
\mathrm{H}_{0}: \text { CDS } \mid \rightarrow \text { LQAS }\end{array}$ & $\begin{array}{l}\text { CS } 1: 12.25 \\
\text { CS } 21.89 \\
\end{array}$ & $\begin{array}{l}\text { Prob1:0.002 } \\
\text { Prob2:0.38 }\end{array}$ & $\begin{array}{l}\text { Unidirectional Cau- } \\
\text { sality } \\
\text { LQAS } \rightarrow \mathrm{CDS}\end{array}$ \\
\hline $\begin{array}{l}\mathrm{H}_{0}: \text { LQST } \mapsto \rightarrow \text { CDS } \\
\mathrm{H}_{0}: \text { CDS } \mid \rightarrow \text { LQST }\end{array}$ & $\begin{array}{l}\text { CS1:9.58 } \\
\text { CS24.25 }\end{array}$ & $\begin{array}{l}\text { Prob1:0.008 } \\
\text { Prob2:0.11 }\end{array}$ & $\begin{array}{l}\text { Unidirectional Cau- } \\
\text { sality } \\
\text { LQST } \rightarrow \text { CDS }\end{array}$ \\
\hline $\begin{array}{l}\mathrm{H}_{0}: \text { LCLA } \mapsto \rightarrow \text { CDS } \\
\mathrm{H}_{0}: \text { CDS } \mid \rightarrow \text { LCLA }\end{array}$ & $\begin{array}{l}\text { CS1:9.07 } \\
\text { CS21.99 }\end{array}$ & $\begin{array}{l}\text { Prob1:0.01 } \\
\text { Prob2:0.36 }\end{array}$ & $\begin{array}{l}\text { Unidirectional Cau- } \\
\text { sality } \\
\text { LCLA } \rightarrow \text { CDS }\end{array}$ \\
\hline $\begin{array}{l}\mathrm{H}_{0}: \text { LCAA } \mapsto \rightarrow \text { CDS } \\
\mathrm{H}_{0}: \text { CDS } \mapsto \rightarrow \text { LCAA }\end{array}$ & $\begin{array}{l}\text { CS1:4.73 } \\
\text { CS21.03 }\end{array}$ & $\begin{array}{l}\text { Prob1:0.09 } \\
\text { Prob2:0.59 }\end{array}$ & No Causality \\
\hline $\begin{array}{l}\mathrm{H}_{0}: \mathrm{FCAF} \mapsto \rightarrow \text { CDS } \\
\mathrm{H}_{0}: \mathrm{CDS} \mapsto \rightarrow \text { FCAF }\end{array}$ & $\begin{array}{l}\text { CS1:0.24 } \\
\text { CS22.93 }\end{array}$ & $\begin{array}{l}\text { Prob1:0.88 } \\
\text { Prob2:0.23 }\end{array}$ & No Causality \\
\hline $\begin{array}{l}\mathrm{H}_{0}: \mathrm{LCDT} \mapsto \rightarrow \mathrm{CDS} \\
\mathrm{H}_{0}: \text { CDS } \mapsto \rightarrow \mathrm{LCDT}\end{array}$ & $\begin{array}{l}\text { CS1:4.14 } \\
\text { CS23.54 }\end{array}$ & $\begin{array}{l}\text { Prob1:0.12 } \\
\text { Prob2:0.17 }\end{array}$ & No Causality \\
\hline $\begin{array}{l}\mathrm{H}_{0}: \text { LRTA I } \rightarrow \text { CDS } \\
\mathrm{H}_{0}: \text { CDS। } \rightarrow \text { LRTA }\end{array}$ & $\begin{array}{l}\text { CS1:0.85 } \\
\text { CS212.36 }\end{array}$ & $\begin{array}{l}\text { Prob1:0.65 } \\
\text { Prob2:0.002 }\end{array}$ & $\begin{array}{l}\text { Unidirectional Cau- } \\
\text { sality } \\
\text { CDS } \rightarrow \text { LRTA }\end{array}$ \\
\hline $\begin{array}{l}\mathrm{H}_{0}: \text { EQUFIX } \mid \rightarrow \text { CDS } \\
\mathrm{H}_{0}: \text { CDS } \mapsto \rightarrow \text { EQUFIX }\end{array}$ & $\begin{array}{l}\text { CS1:3.78 } \\
\text { CS23.63 }\end{array}$ & $\begin{array}{l}\text { Prob1:0.15 } \\
\text { Prob2:0.16 }\end{array}$ & No Causality \\
\hline $\begin{array}{l}\mathrm{H}_{0}: \mathrm{FASS} \mapsto \mathrm{CDS} \\
\mathrm{H}_{0}: \mathrm{CDS} \mid \rightarrow \mathrm{FASS}\end{array}$ & $\begin{array}{l}\text { CS1:3.76 } \\
\text { CS23.28 }\end{array}$ & $\begin{array}{l}\text { Prob1:0.15 } \\
\text { Prob2:0.19 } \\
\end{array}$ & No Causality \\
\hline $\begin{array}{l}\mathrm{H}_{0}: \text { TOTL I } \rightarrow \text { CDS } \\
\mathrm{H}_{0}: \text { CDS } \rightarrow \text { TOTL }\end{array}$ & $\begin{array}{l}\text { CS } 1: 12.41 \\
\text { CS211.15 } \\
\end{array}$ & $\begin{array}{l}\text { Prob1:0.002 } \\
\text { Prob2:0.003 }\end{array}$ & $\begin{array}{l}\text { Bidirectional Causal- } \\
\text { ity }\end{array}$ \\
\hline $\begin{array}{l}\mathrm{H}_{0}: \text { TOTLR } \quad \rightarrow \text { CDS } \\
\mathrm{H}_{0}: \text { CDS } \quad \rightarrow \text { TOTLR }\end{array}$ & $\begin{array}{l}\text { CS1:12.17 } \\
\text { CS214.84 }\end{array}$ & $\begin{array}{l}\text { Prob1:0.002 } \\
\text { Prob2:0.000 }\end{array}$ & $\begin{array}{l}\text { Bidirectional Causal- } \\
\text { ity }\end{array}$ \\
\hline
\end{tabular}




\begin{tabular}{|c|c|c|c|}
\hline $\begin{array}{l}\mathrm{H}_{0}: \mathrm{NPRF} \mid \rightarrow \mathrm{CDS} \\
\mathrm{H}_{0}: \mathrm{CDS} \mid \rightarrow \mathrm{NPRF}\end{array}$ & $\begin{array}{l}\mathrm{CS} 1: 30.16 \\
\mathrm{CS} 21.10\end{array}$ & $\begin{array}{l}\text { Prob1:0.000 } \\
\text { Prob2:0.5 }\end{array}$ & $\begin{array}{l}\text { Unidirectional Cau- } \\
\text { sality } \\
\mathrm{NPRF} \rightarrow \mathrm{CDS}\end{array}$ \\
\hline $\begin{array}{l}\mathrm{H}_{0}: \text { FIXA } \rightarrow \text { CDS } \\
\mathrm{H}_{0}: \text { CDS } \rightarrow \text { FIXA }\end{array}$ & $\begin{array}{l}\text { CS } 1: 17.31 \\
\text { CS25.15 } \\
\end{array}$ & $\begin{array}{l}\text { Prob1:0.000 } \\
\text { Prob2:0.07 } \\
\end{array}$ & $\begin{array}{l}\text { Unidirectional Cau- } \\
\text { sality } \\
\text { FIXA } \rightarrow \text { CDS }\end{array}$ \\
\hline $\begin{array}{l}\mathrm{H}_{0}: \text { INTG } \mid \rightarrow \text { CDS } \\
\mathrm{H}_{0}: \text { CDS } \nrightarrow \text { INTG }\end{array}$ & $\begin{array}{l}\text { CS1:1.07 } \\
\text { CS20.41 }\end{array}$ & $\begin{array}{l}\text { Prob1:0.5 } \\
\text { Prob2:0.8 }\end{array}$ & No Causality \\
\hline $\begin{array}{l}\mathrm{H}_{0}: \text { NINTG } \mid \rightarrow \text { CDS } \\
\mathrm{H}_{0}: \text { CDS } \mid \rightarrow \text { NINTG }\end{array}$ & $\begin{array}{l}\text { CS1:3.89 } \\
\text { CS20.61 }\end{array}$ & $\begin{array}{l}\text { Prob1:0.14 } \\
\text { Prob2:0.73 }\end{array}$ & No Causality \\
\hline $\begin{array}{l}\mathrm{H}_{0}: \text { APRO } \rightarrow \text { CDS } \\
\mathrm{H}_{0}: \text { CDS } \rightarrow \rightarrow \text { APRO }\end{array}$ & $\begin{array}{l}\text { CS } 1: 3.32 \\
\text { CS27.60 } \\
\end{array}$ & $\begin{array}{l}\text { Prob1:0.19 } \\
\text { Prob2:0.002 }\end{array}$ & $\begin{array}{l}\text { Unidirectional Cau- } \\
\text { sality } \\
\text { CDS } \rightarrow \text { APRO }\end{array}$ \\
\hline $\begin{array}{l}\mathrm{H}_{0}: \text { APRE } \mapsto \rightarrow \text { CDS } \\
\mathrm{H}_{0}: \text { CDS } \mapsto \rightarrow \text { APRE }\end{array}$ & $\begin{array}{l}\text { CS1:1.43 } \\
\text { CS28.34 }\end{array}$ & $\begin{array}{l}\text { Prob1:0.48 } \\
\text { Prob2:0.01 }\end{array}$ & $\begin{array}{l}\text { Unidirectional Cau- } \\
\text { sality } \\
\text { CDS } \rightarrow \text { APRE }\end{array}$ \\
\hline $\begin{array}{l}\mathrm{H}_{0}: \text { EBTA } \mid \rightarrow \text { CDS } \\
\mathrm{H}_{0}: \text { CDS } \rightarrow \rightarrow \text { EBTA }\end{array}$ & $\begin{array}{l}\text { CS1:1.82 } \\
\text { CS21.03 }\end{array}$ & $\begin{array}{l}\text { Prob1:0.40 } \\
\text { Prob2:0.53 }\end{array}$ & No Causality \\
\hline $\begin{array}{l}\mathrm{H}_{0}: \text { LCLT } \mapsto \rightarrow \text { CDS } \\
\mathrm{H}_{0}: \text { CDS } \rightarrow \rightarrow \text { LCLT }\end{array}$ & $\begin{array}{l}\text { CS1:8.52 } \\
\text { CS25.61 }\end{array}$ & $\begin{array}{l}\text { Prob1:0.01 } \\
\text { Prob2:0.06 }\end{array}$ & $\begin{array}{l}\text { Unidirectional Cau- } \\
\text { sality } \\
\text { LCLT } \rightarrow \text { CDS }\end{array}$ \\
\hline $\begin{array}{l}\mathrm{H}_{0}: \text { TDTA } \mapsto \rightarrow \text { CDS } \\
\mathrm{H}_{0}: \text { CDS } \mapsto \rightarrow \text { TDTA }\end{array}$ & $\begin{array}{l}\text { CS1:4.02 } \\
\text { CS22.13 }\end{array}$ & $\begin{array}{l}\text { Prob1:0.13 } \\
\text { Prob2:0.34 }\end{array}$ & No Causality \\
\hline $\begin{array}{l}\mathrm{H}_{0}: \text { OOPL } \mid \rightarrow \text { CDS } \\
\mathrm{H}_{0}: \text { CDS } \rightarrow \rightarrow \text { OOPL }\end{array}$ & $\begin{array}{l}\text { CS1:2.31 } \\
\text { CS20.85 }\end{array}$ & $\begin{array}{l}\text { Prob1:0.31 } \\
\text { Prob2:0.91 }\end{array}$ & No Causality \\
\hline
\end{tabular}

(“ $\rightarrow$ " symbols indicates the no causality hypothesis)

Applying least squares regression techniques to evaluate the two models, (1) and (2), produces four types of Granger causality tests: CDS causes PI if we reject $\mathrm{H}_{0}=\beta_{1}=$ $\beta_{2}=\ldots=\beta_{\mathrm{k}}=0$; PI causes CDS if $\mathrm{H}_{0}=\alpha_{1}=\alpha_{2}=\ldots=\alpha_{\mathrm{k}}=0$ is rejected; if both null hypotheses are rejected, (concurrent determination of CDS and PI) feedback is designated; and if neither null hypothesis is rejected, CDS and PI are independent (Walker, 2007).

Table 2 presents Toda and Yamamoto Granger non-causality test results. The " $\mid \rightarrow$ " sign was used instead of the phrase "does not Granger-cause". For instance, ADEQ $\rightarrow$ CDS means ADEQ does not Granger-cause CDS.

Based on the regression analysis and the Granger causality test result, causality directions between the sovereign risk factor and banking performance indicators are summarized in Table 5. 
Table 5. Summary of the Causality Test Results

\begin{tabular}{|c|c|c|}
\hline $\begin{array}{l}\text { Bidirectional } \\
\text { Causality }\end{array}$ & CDS & $\begin{array}{l}\text { ADEQ - Capital Adequacy Ratio (Capital } \\
\text { Adequacy) } \\
\text { TOTL - Total Loans and Receivables / Assets } \\
\text { Total (Asset } \\
\text { TOTLR - Total Loans and Receivables / } \\
\text { Deposits Total (Asset Quality) }\end{array}$ \\
\hline $\begin{array}{l}\text { Unidirectional } \\
\text { Causality }\end{array}$ & $\begin{array}{c}\text { CDS } \\
\text { (Independent) }\end{array}$ & $\begin{array}{l}\text { EQU - Equity / Assets Total (Capital } \\
\text { Adequacy) } \\
\text { LRTA - Loans Received / Total Assets } \\
\text { (Sensitivity) } \\
\text { APRO - Average Profitability of Assets } \\
\text { (Earning } \\
\begin{array}{l}\text { APRE - Average Profitability of Equity } \\
\text { (Earning Quality) }\end{array}\end{array}$ \\
\hline $\begin{array}{l}\text { Unidirectional } \\
\text { Causality }\end{array}$ & $\begin{array}{c}\text { CDS } \\
\text { (Dependent) }\end{array}$ & $\begin{array}{l}\text { LQAS - Liquid Assets / Assets Total } \\
\text { (Liquidity) } \\
\text { LQST - Liquid Assets / Short Term Liabilities } \\
\text { (Liquidity) } \\
\text { LCLA - Local Currency Liquid Assets / Assets } \\
\text { Total } \\
\text { (Liquidity) } \\
\text { NPRF - Non-Performing Loans (Gross) / Total } \\
\text { Loans and Receivables (Asset Quality) } \\
\text { FIXA - Fixed Assets / Assets Total (Asset } \\
\text { Quality) } \\
\text { LCLT - Local Currency Loans and Receivables } \\
\text { / Total Loans and Receivables (Sensitivity) }\end{array}$ \\
\hline
\end{tabular}

Empirical study results indicate that 13 variables out 26 variables have causal relationship with CDS variable according to the Toda Yamamoto Toda and Yamamoto Granger non-causality approach. Among these, with respect to the CAMELS rating system, 2 variables are from the capital adequacy group, 4 variables are from the asset quality group, there is no variable from management quality group, 2 variables from earning quality group, 3 variables from liquidity group, 2 variables from sensitivity group.

\section{Discussion \& Conclusion}

Banks undertake the responsibilities of managing the financial resources of the economies. Problems such as financial distress, failure to fulfill its responsibilities, bankruptcy that may arise in a bank do not only affect the banks and their stakeholders, but also financial system, economic structure and sovereign risk of the country where they operate. Besides, macroeconomic conditions and sovereign risk have influence on banking as well. Macroeconomic conditions such as growth stemming from the economic structures of the countries, foreign trade deficit, current account deficit, 
private and public debt stock, can directly affect the exchange rate and interest rates. Consequently, such changes in the macroeconomic conditions can also affect asset structure, liquidity, credit risks and profitability of the banks in the same system. Therefore, identification of the channels and direction of these interconnectedness' and causalities is important for better management of risks at banking and macroeconomic levels.

With this study, it was aimed to determine the causalities in question and an in-depth research on the empirical usefulness of balance sheet indicators of banks in terms of their exposure of banking performance to sovereign risk is presented. Understanding this interrelation is very important for the formation and implementation of appropriate risk management and financial policies both at micro- and macro-levels.

Empirical results of the study indicated the channels through which the sovereign creditworthiness and banking performance is interaction. These results represents strong interconnectedness between sovereign creditworthiness and "capital adequacy", "asset quality", "management quality", "liquidity" and "sensitivity" of the banks in Turkey. However, causalities between sovereign creditworthiness and banking performance indicators are not in the same direction. Those results, which indicate influence of sovereign creditworthiness on banking performance indicators, are remarkable. Causal relationships between CDS and loan performances of the Turkish Banks, which were defined by this study, proves other researchers, who indicated that effects of sovereign risk may shift to the financial system by means of lending channels (Boyd and De Nicoló, 2005; Wagner, 2010; Ekinci and Poyraz, 2019; Ghenimi et al., 2017). Unidirectional causal relation between CDS variables and liquidity variables as dependent variables supports the studies on spillover effect caused by sovereign risk (Erce, 2015; Mirzaei et al., 2013; Boyd \& De Nicoló, 2005; Wagner, 2010; Ghenimi et al., 2017; Sufian, 2012). The reason may be the fact that stress experienced in the market may cause liquidity problems as banks have limited access to resources in such conditions. Besides, the proven interconnectedness between capital adequacy ratio and sovereign risk indicates the importance of a robust banking industry for a sovereign's economy.

Risk managers in businesses and fiscal bodies of governments should be aware of these channels and patterns of the determinants so that they can develop consistent policies for risk management. Besides, the banking market will attract more capital flows to the country as banks' stocks accumulate based on the improvement of their performance Therefore, the empirical results of this study are interesting for not only risk managers but also regulatory and supervisory agencies including central banks and banking regulation agencies. Furthermore, these findings can help risk monitoring and fiscal policy development efforts increase the robustness of the banking sector and financial system against financial shocks and ensure the achievement of more precise sovereign risk perception regarding the banking industry.

\section{References}

Acharya, V. V. \& Schnabl, P. (2010). Do global banks spread global imbalances? Asset-backed commercial paper during the financial crisis of 2007-09. IMF Economic Review. https://doi.org/10.1057/imfer.2010.4

Aldunate, F. (2019). Deposit insurance, bank risk-taking, and failures: Evidence from early twentieth-century state deposit insurance systems. Review of Corporate 
Finance Studies. https://doi.org/10.1093/rcfs/cfz001

Andreeva, D. C. \& Vlassopoulos, T. (2019). Home bias in bank sovereign bond purchases and the bank-sovereign nexus. International Journal of Central Banking.

Angeloni, C. \& Wolff, G. B. (2012). Are banks affected by their holdings of government debt? Bruegel Working Paper.

Annual Economic Report 2020. (2020). Bank of International Settlement. Retrieved May 29, 2021, from https://www.bis.org/publ/arpdf/ar2020e.htm

Ashcraft, A. B. (2008). Does the market discipline banks? New evidence from regulatory capital mix. Journal of Financial Intermediation. https://doi.org/10.1016/j.jfi.2007.05.003

Avery, R. B., Belton, T. M. \& Goldberg, M. A. (1988). Market discipline in regulating bank risk: New evidence from the capital markets. Journal of Money, Credit and Banking. https://doi.org/10.2307/1992286

BIS. (2011). The impact of sovereign credit risk on bank funding conditions. In Committee on the Global Financial System Papers No. 43.

BIS. (2013). Basel Committee on banking supervision: Core principles for effective banking supervision. In Bank for International Settlements.

Boitan, I. A. \& Marchewka-Bartkowiak, K. (2021). The sovereign-bank nexus in the face of the COVID-19 pandemic outbreak-Evidence from EU member states. Risks, 9(5), 98. https://doi.org/10.3390/risks9050098

Bolton, P. \& Jeanne, O. (2011). Sovereign default risk and bank fragility in financially integrated economies. IMF Economic Review. https://doi.org/10.1057/imfer.2011.5

Bordo, M. D., Meissner, C. M. \& Stuckler, D. (2010). Foreign currency debt, financial crises and economic growth: A long-run view. Journal of International Money and Finance. https://doi.org/10.1016/j.jimonfin.2010.01.002

Boyd, J. H. \& De Nicoló, G. (2005). The theory of bank risk taking and competition revisited. Journal of Finance. https://doi.org/10.1111/j.15406261.2005.00763.x

Brunnermeier, M. K., Garicano, L., Lane, P. R., Pagano, M., Reis, R., Santos, T., Thesmar, D., Van Nieuwerburgh, S. \& Vayanos, D. (2016). The sovereign-bank diabolic loop and esbies. American Economic Review. https://doi.org/10.1257/aer.p20161107

Buch, C. M., Koetter, M. \& Ohls, J. (2016). Banks and sovereign risk: A granular view. Journal of Financial Stability. https://doi.org/10.1016/j.jfs.2016.05.002

Chortareas, G. E., Garza-Garcia, J. G. \& Girardone, C. (2011). Banking sector performance in Latin America: Market power versus efficiency. Review of Development Economics. https://doi.org/10.1111/j.1467-9361.2011.00610.x

Cornett, M. M., McNutt, J. J., Strahan, P. E. \& Tehranian, H. (2011). Liquidity risk management and credit supply in the financial crisis. Journal of Financial Economics. https://doi.org/10.1016/j.jfineco.2011.03.001 
De Bruyckere, V., Gerhardt, M., Schepens, G. \& Vander Vennet, R. (2013). Bank/sovereign risk spillovers in the European debt crisis. Journal of Banking and Finance. https://doi.org/10.1016/j.jbankfin.2013.08.012

Demirgüç-Kunt, A. \& Huizinga, H. (2004). Market discipline and deposit insurance. Statistics and Probability Letters. https://doi.org/10.1016/j.jmoneco.2003.04.001

Demirgüç-Kunt, A. \& Huizinga, H. (2013). Are banks too big to fail or too big to save? International evidence from equity prices and CDS spreads. Journal of Banking and Finance. https://doi.org/10.1016/j.jbankfin.2012.10.010

Ekinci, R. \& Poyraz, G. (2019). The effect of credit risk on financial performance of deposit banks in Turkey. Procedia Computer Science. https://doi.org/10.1016/j.procs.2019.09.139

Erce, A. (2015). Bank and Sovereign Risk Feedback Loops. Federal reserve bank of dallas, globalization and monetary policy institute. Working Papers. https://doi.org/10.24149/gwp227

Federal Deposit Insurance Corporation. (1996). Uniform financial institutions rating System. Federal Register.

Ghenimi, A., Chaibi, H. \& Omri, M. A. B. (2017). The effects of liquidity risk and credit risk on bank stability: Evidence from the MENA region. In Borsa Istanbul Review. https://doi.org/10.1016/j.bir.2017.05.002

Global Economic Prospects. (2021). World Bank. Retrieved May 29, 2021, from https://www.worldbank.org/en/publication/global-economic-prospects

Global Financial Stability Report: Markets in the Time of COVID-19. (2020). International Monetary Fund. Retrieved May 9, 2021, from https://www.imf.org/en/Publications/GFSR/Issues/2020/04/14/globalfinancial-stability-report-april-2020

Grigorian, D. \& Manole, V. (2016). Sovereign risk and deposit dynamics: Evidence from Europe. IMF Working Papers. https://doi.org/10.5089/9781498381833.001

Gunning, G. (2012). Standard \& Poor's new banking criteria levels the financial markets. InFinance.

Hirtle, B. J. \& Lopez, J. A. (1999). Supervisory information and the frequency of bank examinations. Economic Policy Review.

Huizinga, H. \& Laeven, L. (2019). The Procyclicality of banking: Evidence from the euro area. IMF Economic Review. https://doi.org/10.1057/s41308-019-00081-5

International Monetary Fund. (2017). Turkey: Financial sector assessment program: detailed assessment of observance-assessment of observance of the CPMIIOSCO principles for financial market infrastructure. IMF Staff Country Reports. https://doi.org/10.5089/9781475576870.002

Kirikkaleli, D. \& Gokmenoglu, K. K. (2019). Sovereign credit risk and economic risk in Turkey: Empirical evidence from a wavelet coherence approach. Borsa Istanbul Review. https://doi.org/10.1016/j.bir.2019.06.003 
Levy-Yeyati, E., Martínez Pería, M. S. \& Schmukler, S. L. (2010). Depositor behavior under macroeconomic risk: Evidence from bank runs in emerging economies. Journal of Money, Credit and Banking. https://doi.org/10.1111/j.15384616.2010.00300.x

Lopez, J. A. (1999). Using CAMELS ratings to monitor bank conditions. Federal Reserve Bank of San Francisco Economic Letter.

Martínez Pería, M. S. \& Schmukler, S. L. (2001). Do depositors punish banks for bad behavior? Market discipline, deposit insurance, and banking crises. Journal of Finance. https://doi.org/10.1111/0022-1082.00354

Mirzaei, A., Moore, T. \& Liu, G. (2013). Does market structure matter on banks' profitability and stability? Emerging vs. advanced economies. Journal of Banking and Finance. https://doi.org/10.1016/j.jbankfin.2013.04.031

Mishkin, F. S. \& Carey, M. (2013). Dimensions of credit risk and their relationship to economic capital requirements. In Prudential Supervision. https://doi.org/10.7208/chicago/9780226531939.003.0006

Podstawski, M. \& Velinov, A. (2018). The state dependent impact of bank exposure on sovereign risk. Journal of Banking and Finance. https://doi.org/10.1016/j.jbankfin.2017.11.002

Qamruzzaman, M. \& Wei, J. (2019). Do financial inclusion, stock market development attract foreign capital flows in developing economy: a panel data investigation. Quantitative Finance and Economics. https://doi.org/10.3934/qfe.2019.1.88

Rahman, M. Z. \& Islam, M. S. (2017). Use of CAMEL rating framework: A comparative performance evaluation of selected Bangladeshi private commercial banks. International Journal of Economics and Finance. https://doi.org/10.5539/ijef.v10n1p120

Rambaldi, A. \& Doran, H. (1996). Testing for granger non-causality in cointegrated systems made easy. In Working paper.

Shair, F., Sun, N., Shaorong, S., Atta, F. \& Hussain, M. (2019). Impacts of risk and competition on the profitability of banks: Empirical evidence from Pakistan. PLoS ONE. https://doi.org/10.1371/journal.pone.0224378

Sufian, F. (2012). Determinants of bank profitability in developing economies: Empirical evidence from the South Asian banking sectors. Contemporary South Asia. https://doi.org/10.1080/09584935.2012.696089

Toda, H. Y. \& Yamamoto, T. (1995). Statistical inference in vector autoregressions with possibly integrated processes. Journal of Econometrics. https://doi.org/10.1016/0304-4076(94)01616-8

Wagner, W. (2010). Loan market competition and bank risk-taking. Journal of Financial Services Research. https://doi.org/10.1007/s10693-009-0073-8

Walker, D. M. (2007). The economics of casino gambling. In The Economics of Casino Gambling. https://doi.org/10.1007/978-3-540-35104-7

Zapata, H. O. \& Rambaldi, A. N. (1997). Monte Carlo evidence on cointegration and causation. Oxford Bulletin of Economics and Statistics. 
https://doi.org/10.1111/1468-0084.00065 